\title{
Renal patients' views on generic prescribing and substitution: example from the United Arab Emirates
}

\author{
M.N. Al Ameri, ${ }^{1,2}$ W. Mohamed, ${ }^{2}$ E. Makramalla, ${ }^{2}$ B. Shalhoub, ${ }^{3}$ A. Tucker ${ }^{1}$ and A. Johnston ${ }^{7}$
}

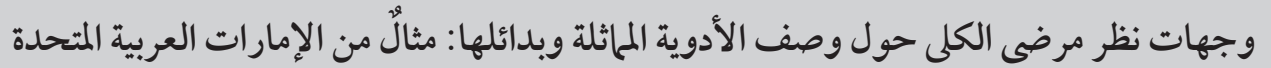

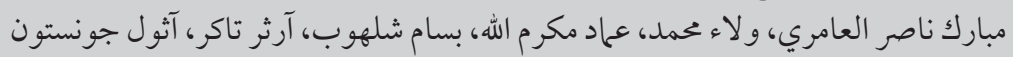

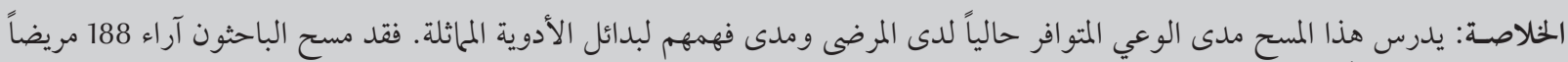

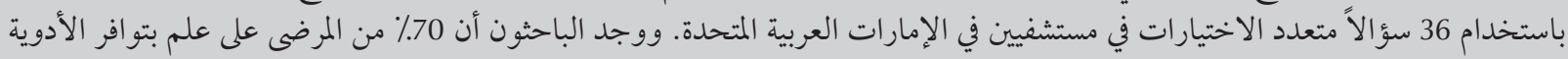

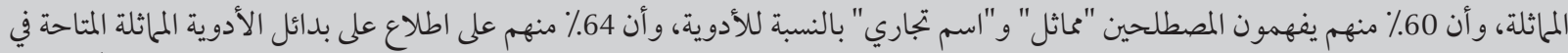

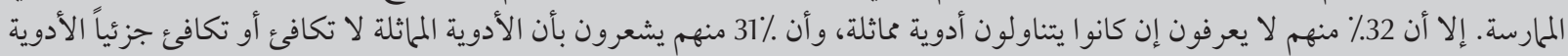

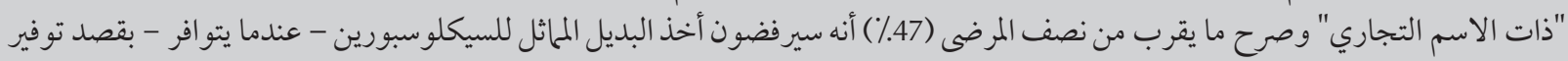

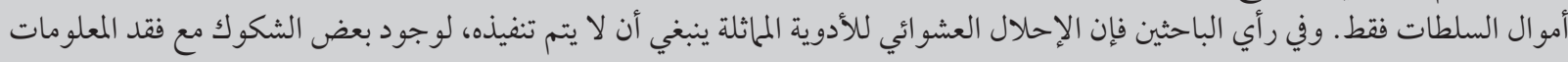
الكافية حولها لدى المرضى.

ABSTRACT This survey examined current patient awareness and understanding of generic substitution. We surveyed 188 renal patients using 36 multiple-choice questions in 2 hospitals in the United Arab Emirates. We found that $70 \%$ of patients were aware of the availability of generic medicines, $60 \%$ understood the terms "generic" and "branded" in relation to medicines and $64 \%$ were conscious of generic substitution practice. However, 32\% did not know if they were taking generics and 31\% felt that generics were not equivalent or only sometimes equivalent to branded medicines. Nearly half $(47 \%)$ the patients stated they would refuse generic substitution of ciclosporin when it became available if this was just to save the health authority money. In our opinion, random generic substitution should not be implemented because there is still uncertainty and lack of knowledge among patients.

Points de vue des patients atteints d'une maladie rénale sur la prescription des génériques et leur utilisation en substitution : exemple des Émirats arabes unis

RÉSUMÉ La présente étude a examiné les connaissances et la compréhension actuelles des patients en matière de substitution par des génériques. Nous avons enquêté auprès de 188 patients atteints d'une maladie rénale à l'aide de 36 questions à choix multiples dans deux hôpitaux des Émirats arabes unis. Nous avons trouvé que $70 \%$ des patients connaissaient la disponibilité des médicaments génériques, $60 \%$ comprenaient les termes " génériques » et « de marque » pour les médicaments et 64 \% étaient conscients de la pratique de substitution par des génériques. Toutefois, $32 \%$ des patients ignoraient s'ils prenaient des génériques et $31 \%$ avaient le sentiment que les génériques n'étaient pas équivalents ou n'étaient que parfois équivalents aux médicaments de marque. Près de la moitié (47 \%) des patients ont précisé qu'ils refuseraient une substitution par un générique de la ciclosporine quand ce dernier deviendra disponible, s'il s'agissait uniquement de permettre aux autorités de santé de faire des économies. À notre avis, la substitution par des génériques ne doit pas être mise en œuvre de manière aléatoire en raison de l'incertitude et des faibles connaissances des patients. 


\section{Introduction}

In the last 2 decades healthcare costs have been climbing globally. For example, spending on drugs in the United Kingdom represents over $10 \%$ of the total health service budget, and has increased steadily over recentdecades [1]. In the United Arab Emirates (UAE), the consumption of medicine reached 4 billion UAE dirhams in 2010 [2]. In the next 2 decades, healthcare expenditure is predicted to rise from US\$ 14 billion in 2008 to US\$ 60 billion in the countries of the Gulf [2]. As a result, many countries may be encouraged to reduce their healthcare expenditures. Prescribing generic equivalents of branded drugs could markedly lower medication costs. This strategy has proven to be effective since it is often easier to intervene on expenditure on medicines because of their identified cost $[3,4]$.

About $85 \%$ of the UAE pharmaceutical market consists of branded products, therefore, in the UAE medicines are mostly prescribed and dispensed in their branded form. Most of the pharmacies in the government hospitals promote branded medicines, resulting in a huge burden for the cost of treatment. Physicians also prescribe medicines by their trade names. Despite the availability of generics for some out-of-patent brands, physician still prescribe the branded form. For instance, the branded prescribing of Augmentin, Glucophage, Voltaren and Zocor is still growing despite the availability of a certain amount of generic competition [5].

In the 3 years since 2009, private health insurance has grown dramatically in the UAE. This, as a result, improved the regulators' ability to coordinate healthcare development in a direction that is beneficial to both the consumer and the pharmaceutical industry.

In addition to prohibiting directto-consumer marketing, a new rule requires physicians to prescribe using chemical names and choosing from a list of medicines (the hospital formulary) to overcome the influence of pharmaceutical companies [5].

Generic substitution has raised concerns about whether it serves the interests of patients or the target of reducing healthcare costs. Indeed some authors are now questioning the quality of some cheaper drugs [6-8]. Cost could be a very important factor in drug substitution and prescribability-the physician's first consideration for prescribing between a branded drug and its generic counterpart for a new patient [9]. However, drug substitution can be considered more critical than drug prescribability for patients who have been on branded medicine for a long time. Therefore, there are some safety and ethical issues around switching patients from a branded to a generic drug $[8,10]$. This issue of drug substitution can easily mislead patients and doctors by supporting misconceptions about generic drugs and substitution $[11,12]$. Some healthcare providers have been promoting generic substitution in an attempt to contain costs $[13,14]$ although it may be difficult to determine the extent of any long term savings. Drug substitution may involve spending or costs additional to the simple product acquisition costs.

Health service providers and payers are also promoting generic substitution and are not prepared to consider that there may be a problem in that patient outcomes could be detrimentally affected, reducing potential savings from these substitutions and laying the providers open to legal redress from patients adversely affected by the substitution policies [15-17].

Generic substitution could reduce the United Kingdom (UK) National Health Service brand medicine bill by $£ 80$ million, based on a peak yearly spend of $£ 8$ billion [14]. Generics account for $83 \%$ of general practitioner prescribingin the United Kingdom [18]. Likewise, in Germany, health insurance could save $€ 1.5$ billion if prescriptions were fully generically dispensed [19]. In the United States of America (USA) generic drugs accounted for $47 \%$ of all prescriptions dispensed in 1999, $61 \%$ in 2006 and 69\% in 2008 [20]. Approving generic drugs in the USA has resulted in average savings of $77 \%$ of the product cost within 1 year [21].

It is well known that patient compliance can be attained when substitution is promoted after providing information, knowledge and education. The objective of this survey was, therefore, to evaluate current awareness, knowledge and understanding about generic substitution among renal patients' in the UAE and how the medical professionals are dealing with this issue, which directly involve patients.

\section{Methods}

We carried out this multicentre survey in the nephrology departments of 2 tertiary hospitals in the United Arab Emirates (UAE), the "UAE General Hospital" and the "UAE University Hospital" (the names of the hospitals were kept anonymous to comply with their rules). This survey was approved by the administration of the UAE General Hospital and by Al Ain Medical District Human Research Ethics Committee - Protocol No. 10/64. The questionnaire had been piloted and validated previously in the Royal London Hospital in the United Kingdom for a survey carried out in that hospital [22]. The questionnaire was available in both English and Arabic to cover all patients.

The aim and the protocol of the survey was explained and discussed with the medical professionals involved in the study in both hospitals. Renal patients over 18 years, able to read and write English and/or Arabic, and willing to fill in the questionnaire were targeted. This group of patients were specified in this survey because any small changes in the medicinal effect 
can negatively impact on their clinical outcome. This survey was related to all medications, not immunosuppressant agents alone.

According to the study protocol, a minimum of 100 patients were required to be surveyed in each hospital. However, nurses and pharmacists in the participating hospitals were only able to recruit a total of 188 patients: 101 patients treated at the UAE General Hospital and 87 patients treated at the UAE University Hospitals. It was difficult to enrol a higher number of patients during the regular clinic hours because of time constraints.

The questionnaire (developed by the principal researcher) used as a tool to obtain the required information had 36 multiple-choice, closed questions. Patients booked in for clinic visit were recruited by clinical pharmacists and nursing staff as patients over a period of 1 year (1 July 2010-1 January 2011 in the UAE General Hospital and 1 February 2011-1 July 2011 in the UAE University Hospital). After reviewing the information sheet which contained a brief introduction in English or Arabic about generic medicines and substitution, patients consented by agreeing to fill in the questionnaire. A researcher was available to clarify any unclear points.

The data from the questionnaire were analysed using Microsoft Excel 2007 and Minitab 16 statistical software. Results are reported as percentage plus 95\% confidence interval (CI). Missing values are not included in the calculations of percentages; the total number of respondents for each question is given in parentheses after each question.

\section{Results}

A total of $122(65 \%)$ male and 66 (35\%) female patients with average age 49 (range 18-86; median 50) years were included in this study (Table 1).

\begin{tabular}{|c|c|c|}
\hline Characteristic & No. & $\%(95 \% \mathrm{Cl})$ \\
\hline \multicolumn{3}{|l|}{ Sex } \\
\hline Male & 122 & $65(58-72)$ \\
\hline Female & 66 & $35(28-42)$ \\
\hline \multicolumn{3}{|l|}{ Age distribution (years) } \\
\hline$\leq 39$ & 41 & $22(16-29)$ \\
\hline $40-49$ & 48 & $26(20-33)$ \\
\hline $50-59$ & 59 & $32(25-39)$ \\
\hline $60+$ & 38 & $20(15-27)$ \\
\hline \multicolumn{3}{|c|}{ No. of medications taken daily } \\
\hline $1-3$ & 62 & $34(27-41)$ \\
\hline $4-6$ & 82 & $44(37-52)$ \\
\hline $7-9$ & 18 & $10(6-15)$ \\
\hline$>9$ & 22 & $12(8-18)$ \\
\hline \multicolumn{3}{|c|}{ Time of organ transplant ${ }^{a}$} \\
\hline$<1$ year ago & 8 & $4(2-8)$ \\
\hline$\geq 1$ year ago & 29 & $16(11-22)$ \\
\hline Only dialysis & 149 & $80(74-86)$ \\
\hline \multicolumn{3}{|l|}{ Education level } \\
\hline Secondary school & 46 & $29(22-36)$ \\
\hline Vocational training & 20 & $12(8-19)$ \\
\hline Sixth form & 0 & $0(0-2)$ \\
\hline College & 29 & $18(12-25)$ \\
\hline University & 53 & $33(26-41)$ \\
\hline Postgraduate & 13 & $8(4-13)$ \\
\hline
\end{tabular}

Some data are missing for most questions. $\mathrm{CI}=$ confidence interval.

The majority [80\% (95\% CI: 74-86)] of the participants were on kidney dialysis at the time of the survey. A total of 95 participants were classified as highly educated (graduated from college, university or postgraduate), and 66 participants were classed as less-educated (graduated from secondary school, vocational training or sixth form) (Table 1).

Many patients [70\%, (95\% CI: 64-77)] stated that they were aware of the availability of different forms of the same medicine and 60\% (95\% CI: 53-67) said that they understood the terms "generic" and "branded" in relation to medicines(Table 2). Only 33\% (95\% CI: 26-40) of patients felt that generics are always equivalent to branded medicines.
Many patients [85\% (95\% CI: 78-90)] were unaware or uncertain about the availability of the generic form of ciclosporin in the global market and 47\% (95\% CI: 40-55) stated that they would refuse generic substitution of ciclosporin if it become available in local hospitals (Table 2).

The effect of education on patients' acceptance of generic medicines and substitution was marked in this survey. A total of 93 highly educated patients (graduated from college, university or postgraduate) responded to a question evaluating their awareness of generic substitution practice, and $84 \%$ of these were aware of the practice, while from the 64 less educated (graduated from secondary school, vocational training or sixth 


\begin{tabular}{|c|c|c|c|}
\hline Question & Response & No. & $\%(95 \% \mathrm{Cl})$ \\
\hline \multirow{3}{*}{$\begin{array}{l}\text { Were you aware that there are different forms of the same medicine available, } \\
\text { produced by different manufacturers? }\left(n^{r}=185\right)\end{array}$} & Yes & 130 & $70(63-77)$ \\
\hline & No & 32 & $17(12-24)$ \\
\hline & Uncertain & 23 & $13(8-18)$ \\
\hline \multirow{3}{*}{$\begin{array}{l}\text { Do you understand the terms "generic" and "branded" in relation to medicines? } \\
\left(n^{r}=185\right)\end{array}$} & Yes & 111 & $60(53-67)$ \\
\hline & No & 61 & $33(26-40)$ \\
\hline & Uncertain & 13 & $7(4-12)$ \\
\hline \multirow[t]{3}{*}{ Are you aware of the generic substitution practice? $\left(n^{r}=185\right)$} & Yes & 119 & $64(57-71)$ \\
\hline & No & 18 & $10(6-15)$ \\
\hline & Uncertain & 48 & $26(20-33)$ \\
\hline \multirow[t]{3}{*}{ Are you currently taking any generic prescription medications? $\left(n^{r}=183\right)$} & Yes & 52 & $29(22-36)$ \\
\hline & No & 72 & $39(32-47)$ \\
\hline & Uncertain & 59 & $32(26-40)$ \\
\hline \multirow{3}{*}{$\begin{array}{l}\text { Were you aware that a generic form of ciclosporin is available in most of the } \\
\text { hospitals abroad? }\left(n^{r}=138\right)\end{array}$} & Yes & 21 & $15(10-22)$ \\
\hline & No & 110 & $80(72-86)$ \\
\hline & Uncertain & 7 & $5(2-10)$ \\
\hline \multirow{3}{*}{$\begin{array}{l}\text { Would you agree to switch your current branded ciclosporin to a generic form } \\
\text { to save the local health authority money? }\left(n^{r}=178\right)\end{array}$} & Agree & 51 & $29(22-36)$ \\
\hline & Disagree & 84 & $47(40-55)$ \\
\hline & Uncertain & 43 & $24(18-31)$ \\
\hline \multirow{4}{*}{$\begin{array}{l}\text { Do you think that generic medicines are equivalent and have the same quality } \\
\text { as the branded medicines? }\left(n^{r}=182\right)\end{array}$} & Yes, always & 59 & $33(26-40)$ \\
\hline & No, never & 53 & $29(23-36)$ \\
\hline & Yes, sometimes & 4 & $2(0-6)$ \\
\hline & Uncertain & 66 & $36(29-44)$ \\
\hline
\end{tabular}

$n^{r}=$ total number of patients responding to the question .

$\mathrm{Cl}=$ confidence interval.

form) patients who responded to the same question, only $45 \%$ were aware of the practice. Furthermore, from the 95 highly educated renal patients who responded to the question, 39\% said that they would accept generic substitution of the drug, while from the 62 less educated patients who responded to the same question, only $18 \%$ confirmed that they would accept the substitution (Table 3).

Patients were asked to rate their satisfaction with generic drugs. From a total of 36 highly educated patients who answered this question, almost half $[47 \%$ (95\% CI: 30-65)] stated that they were very satisfied, while from a total of 26 less-educated patients who answered the same question, only 6 [23\% (95\% CI: 9-44)] said that they were very satisfied.

\begin{tabular}{|c|c|c|c|c|c|c|c|}
\hline \multirow[t]{2}{*}{ Question } & \multirow[t]{2}{*}{ Choice } & \multicolumn{3}{|c|}{$\begin{array}{l}\text { Highly educated patients }{ }^{\mathrm{a}} \\
\qquad(\boldsymbol{n}=93)\end{array}$} & \multicolumn{3}{|c|}{$\begin{array}{l}\text { Less-educated patients } \\
\qquad(n=64)\end{array}$} \\
\hline & & No. & $\%$ & $95 \% \mathrm{Cl}$ & No. & $\%$ & $95 \% \mathrm{Cl}$ \\
\hline \multirow{3}{*}{$\begin{array}{l}\text { Are you aware of the practice of } \\
\text { generic substitution? }\end{array}$} & Yes & 78 & 84 & 75-91 & 29 & 45 & $33-58$ \\
\hline & No & 5 & 5 & $2-12$ & 7 & 11 & $5-21$ \\
\hline & Not sure & 10 & 11 & 5-19 & 28 & 44 & $31-57$ \\
\hline \multirow{3}{*}{$\begin{array}{l}\text { Would you agree to switch your } \\
\text { current branded ciclosporin?c }\end{array}$} & Yes & 36 & 39 & $30-65$ & 11 & 18 & $9-44$ \\
\hline & No & 32 & 35 & $29-50$ & 37 & 60 & $46-72$ \\
\hline & Uncertain & 24 & 26 & $17-36$ & 14 & 23 & 13-35 \\
\hline
\end{tabular}

${ }^{a}$ Graduated from college, university or postgraduate.

${ }^{b}$ Graduated from secondary school, vocational training or sixth form.

${ }^{c} n=92$ for educated patients and 62 for less-educated patients.

$\mathrm{Cl}=$ confidence interval. 


\section{Attitudes towards generic medicines and substitution}

Most of the patients [66\% (95\% CI: 53-77)] who had ever received generic medicines were dissatisfied or uncertain about their satisfaction concerning the generic alternative (Table 4). Only 33\% (95\% CI: 26-41) felt that being prescribed generic medicines would not affect their adherence to the medication regime.

Severity of disease also influenced patients' acceptance of generic substitution: 92 of the 183 participants who responded to this question stated that they would accept generic substitution if they had mild disease compared to only $43 / 181$ [24\% (95\% CI: 18-31) who would still do so if they had a chronic disease.

\section{Influence of professionals on patients' acceptance of generic medicines and substitution}

We found that $17 \%$ (95\% CI: 11-22) of 175 respondents stated that their doctor had changed their medicine to a generic form (Table 5). The majority of these patients $[87 \%$ (95\% CI: 79-93)], however, said that they were either not monitored or were uncertain about being monitored after switching their medicine to generic. Moreover, 54\% (95\% CI: 44-64) declared that no background information regarding generics and substitution was provided. According to $26 \%$ (95\% CI: 20-34) of patients, pharmacist was the main source of information regarding generic substitution. Of theses, 74\% (95\% CI: 64-84) admitted that most information was given verbally. The reasons for switching their medicines were not discussed at all with 33\% (95\% CI: 24-43).

The vast majority of our participants (88\%; 95\% CI: 83-92) wished to be always notified when their medicines were switched (Table 5). More than half (59\%; 95\% CI: 51-66), believed that they should be consulted by hospital specialists or by both the general

\begin{tabular}{|c|c|c|c|c|}
\hline Question & Response & No. & $\%$ & $95 \% \mathrm{Cl}$ \\
\hline \multirow{5}{*}{$\begin{array}{l}\text { Which of the following do you think may be the } \\
\text { potential reason for switching your medicine to } \\
\text { the generic form? }\left(n^{r}=153\right)\end{array}$} & $\begin{array}{l}\text { Save the Ministry of Health } \\
\text { money }\end{array}$ & 56 & 37 & $29-45$ \\
\hline & Generics are more effective & 8 & 5 & $2-10$ \\
\hline & $\begin{array}{l}\text { Generics have the same } \\
\text { effectiveness and less costs }\end{array}$ & 43 & 28 & $21-36$ \\
\hline & $\begin{array}{l}\text { The branded medicine was not } \\
\text { available }\end{array}$ & 45 & 29 & $22-37$ \\
\hline & Other & 1 & 1 & $0-4$ \\
\hline \multirow{3}{*}{$\begin{array}{l}\text { Do you think that receiving a generic medicine } \\
\text { might affect how regularly you take your } \\
\text { medicines? }\left(n^{r}=174\right)\end{array}$} & Yes & 48 & 28 & $21-35$ \\
\hline & No & 58 & 33 & $26-41$ \\
\hline & Uncertain & 68 & 39 & $32-47$ \\
\hline \multirow{3}{*}{$\begin{array}{l}\text { How satisfied are you with the generic alternative } \\
\text { that you are taking? }{ }^{\mathrm{a}}\left(n^{r}=70\right)\end{array}$} & Very satisfied & 24 & 34 & $23-47$ \\
\hline & Dissatisfied & 20 & 29 & $18-41$ \\
\hline & Neither satisfied nor dissatisfied & 26 & 37 & $26-50$ \\
\hline \multirow{3}{*}{$\begin{array}{l}\text { Have you experienced any differences in terms } \\
\text { of effectiveness or side-effects between branded } \\
\text { and generic medicines? }\left(n^{r}=72\right)\end{array}$} & Yes & 32 & 44 & $33-57$ \\
\hline & No & 31 & 43 & $31-55$ \\
\hline & Uncertain & 9 & 13 & $6-22$ \\
\hline \multirow{3}{*}{$\begin{array}{l}\text { Do you think adapting to these differences was a } \\
\text { concern? }\left(n^{r}=52^{\mathrm{b}}\right)\end{array}$} & Yes & 24 & 46 & $32-61$ \\
\hline & No & 10 & 19 & $10-33$ \\
\hline & Uncertain & 18 & 35 & $22-49$ \\
\hline \multirow{7}{*}{$\begin{array}{l}\text { What differences between the branded and } \\
\text { generic medicines have you experienced or } \\
\text { heard of? }\left(n^{r}=107\right)\end{array}$} & Packaging & 26 & 24 & $17-34$ \\
\hline & Shape, colour or taste & 22 & 20 & $13-29$ \\
\hline & Brand was more effective & 31 & 29 & $21-39$ \\
\hline & Generic was more effective & 3 & 3 & $0-8$ \\
\hline & Brand had more side-effects & 2 & 2 & $0-7$ \\
\hline & Generic had more side-effects & 22 & 21 & $13-29$ \\
\hline & Other & 1 & 1 & $0-5$ \\
\hline
\end{tabular}

$n^{r}=$ total number of patients responding to the question.

${ }^{a}$ Number of patients on generic medicines $=81$.

${ }^{b}$ Out of the 72 who experienced differences.

$\mathrm{Cl}=$ confidence interval. 


\begin{tabular}{|c|c|c|c|}
\hline Question & Response & No. & $\%(95 \% \mathrm{Cl})$ \\
\hline \multirow{4}{*}{$\begin{array}{l}\text { In general, how far do you feel your doctor involves you in } \\
\text { decisions regarding your medications? }\left(\mathrm{n}^{r}=175\right)\end{array}$} & A lot & 82 & $47(39-54)$ \\
\hline & A bit & 71 & $41(33-48)$ \\
\hline & Not at all & 18 & $10(6-16)$ \\
\hline & Uncertain & 4 & $2(0-6)$ \\
\hline \multirow{3}{*}{$\begin{array}{l}\text { Has your doctor ever told you to make sure that you always } \\
\text { receive the same brand of any medicine? }\left(n^{r}=175\right)\end{array}$} & Yes & 29 & $17(11-23)$ \\
\hline & No & 142 & $81(75-87)$ \\
\hline & Uncertain & 4 & $2(0-6)$ \\
\hline \multirow{3}{*}{$\begin{array}{l}\text { Would you agree to switch your medicine to a generic } \\
\text { alternative if your doctor felt that the } 2 \text { medicines were } \\
\text { interchangeable? }\left(\mathrm{n}^{r}=104\right)\end{array}$} & Agree & 74 & $71(61-80)$ \\
\hline & Disagree & 17 & $16(10-25)$ \\
\hline & Uncertain & 13 & $13(7-20)$ \\
\hline \multirow{3}{*}{$\begin{array}{l}\text { How much would you favour or oppose a requirement that } \\
\text { patients always be notified if their medicine is changed to a } \\
\text { generic form? }\left(n^{r}=178\right)\end{array}$} & Favour & 156 & $88(82-92)$ \\
\hline & Oppose & 12 & $7(4-11)$ \\
\hline & Neither favour nor oppose & 10 & $5(3-10)$ \\
\hline \multirow{4}{*}{$\begin{array}{l}\text { Do you think that you should be consulted about being given } \\
\text { generic medicines? }\left(n^{r}=188\right)\end{array}$} & Yes, by general practitioner & 26 & $14(9-20)$ \\
\hline & Yes, by hospital specialist & 56 & $30(23-37)$ \\
\hline & $\begin{array}{l}\text { Agreement of both general } \\
\text { practitioner and hospital specialist }\end{array}$ & 54 & $29(23-36)$ \\
\hline & Do not think that this is necessary & 52 & $27(21-34)$ \\
\hline \multirow{3}{*}{$\begin{array}{l}\text { Has your doctor ever changed your medicine to a generic form? } \\
\left(n^{r}=175\right)\end{array}$} & Yes & 29 & $17(11-22)$ \\
\hline & No & 142 & $81(75-87)$ \\
\hline & Uncertain & 4 & $2(0-6)$ \\
\hline \multirow{3}{*}{$\begin{array}{l}\text { Did your doctor monitor the effect of your medicine after } \\
\text { switching you to a generic medicine? }\left(n^{r}=106\right)\end{array}$} & Yes & 14 & $13(7-21)$ \\
\hline & No & 50 & $47(37-57)$ \\
\hline & Uncertain & 42 & $40(30-50)$ \\
\hline \multirow{3}{*}{$\begin{array}{l}\text { Did anyone provide you with background information about } \\
\text { your generic medicine? }\left(n^{r}=105\right)\end{array}$} & Yes & 40 & $38(29-48)$ \\
\hline & No & 57 & $54(44-64)$ \\
\hline & Uncertain & 8 & $8(3-14)$ \\
\hline \multirow[t]{6}{*}{ Who provided you with background information? $\left(n^{r}=168\right)$} & Specialist & 38 & $23(17-30)$ \\
\hline & Hospital doctor & 39 & $23(17-30)$ \\
\hline & General practitioner & 39 & $23(17-30)$ \\
\hline & Pharmacist & 44 & $26(20-34)$ \\
\hline & Nurse & 6 & $4(1-8)$ \\
\hline & Other & 2 & $1(0-4)$ \\
\hline \multirow{3}{*}{$\begin{array}{l}\text { Did you consider the information provided about your generic } \\
\text { medicine sufficient? }\left(n^{r}=63\right)\end{array}$} & Yes & 30 & $48(35-61)$ \\
\hline & No & 12 & $19(10-31)$ \\
\hline & Uncertain & 21 & $33(22-46)$ \\
\hline \multirow{3}{*}{$\begin{array}{l}\text { Did anyone discuss the reasons for switching your medicine to } \\
\text { the generic form? }\left(n^{r}=100\right)\end{array}$} & Yes & 65 & $65(55-74)$ \\
\hline & No & 33 & $33(24-43)$ \\
\hline & Uncertain & 2 & $2(0-7)$ \\
\hline \multirow{6}{*}{$\begin{array}{l}\text { Who discussed the reasons for switching your medicine to the } \\
\text { generic form? Choose all applicable }\left(n^{r}=194\right)\end{array}$} & Specialist & 51 & $27(20-33)$ \\
\hline & Hospital doctor & 45 & $23(17-30)$ \\
\hline & General practitioner & 41 & $21(16-28)$ \\
\hline & Pharmacist & 9 & $25(19-32)$ \\
\hline & Nurse & 8 & $4(2-8)$ \\
\hline & Other & 0 & $0(0-2)$ \\
\hline
\end{tabular}

$n^{r}=$ total number of patients responding to the question.

$\mathrm{Cl}=$ confidence interval. 
practitioner and the hospital specialist before having their medicine switched. Nevertheless, 69\% (95\% CI: 63-76) of respondents stated that they would be more likely to accept generic substitution if it was initiated by a hospital consultant/hospital doctor (Table 6).

\section{Discussion}

Many of our participants were familiar with the availability of different formulations of the same medicine and understood the term generic versus branded medications. In addition, many patients were able to define the generic substitution practice. However, many did not know whether if their medicine was substituted to a generic or if they were currently on generic medicines. Several were not convinced about generic medicines and substitution. These attitudes were mainly found in patients with less education, those not involved in their healthcare decisions and those who believed that substitution was mostly performed because of a shortage in the healthcare budget or in the availability of the branded medicine. These attitudes might also be related to the belief that the cheaper medicine must be inferior to the more expensive branded medicines [23].

It is clear in this study that there are factors affecting patients' decisions concerning their health. Those include education level, knowledge and the severity of disease. Highly educated patients were more knowledgeable about the practice of substitution and were therefore more accepting of generic substitution of ciclosporin than those with a lower level of education. However, there were still some highly educated patients who were unsure about the efficiency of generic medicine and substitution. These patients were not assured by their healthcare professionals about the safety and the effectiveness of the drug substitution.

Undoubtedly, the effort and time spent by healthcare professionals in monitoring patients after switching their medicine is very important to assure adherence. Most of the renal patients in this survey favoured always being notified when their medicines are switched; this might positively affect their acceptance of drug substitution. Many others would agree to accept generic substitution if they were informed clearly. This is supported by the results of a similar study on renal patients in the UK [22]. This indicates a need for educating patients and for clarifying the reasons for generic substitution and the roles of healthcare professionals in successfully introducing this practice.

Patients also reported that most information was given to them orally by pharmacists. It has been recommended that patients should be given information in written form to allow reviewing and remembering the complex medical information whenever needed [24].
However, a survey evaluating the level of interaction between physicians and community pharmacists in the UAE showed that $60 \%$ of physicians rarely or never discussed patients' drug therapy with pharmacists [25].

The guidelines for approving bioequivalency of generic medicines in the UAE are mostly based on the guidelines of the World Health Organization, the European Medicines Agency, the Food and Drug Administration in the USA, and the International Conference on Harmonization. For example, to approve interchangeability between 2 medicines, they should be demonstrated as therapeutically equivalent to one another through bioequivalence studies, comparative clinical trials and/ or in vitro dissolution tests [26].

Our findings are comparable with those in the other studies. Although there are few published articles evaluating patients' views on generic substitution in the UAE, some have shown that drug substitution can be problematic $[23,27]$. Small differences in some particular drugs during manufacturing could theoretically result in significant adverse effects or loss of efficacy $[7,28]$. A large number of studies have been conducted to evaluate the potential effect of generic substitution on the clinical outcome. Some of these have concluded that generic substitution had unexpected and negative effects $[29,30]$.

Anumber of studies have shown differences in the pharmacokinetic profile

\begin{tabular}{|c|c|c|c|c|c|c|}
\hline \multirow[t]{3}{*}{ Question } & \multicolumn{6}{|c|}{ Response } \\
\hline & \multicolumn{2}{|r|}{ Yes } & \multicolumn{2}{|c|}{ No } & \multicolumn{2}{|c|}{ Uncertain } \\
\hline & No. & $\%(95 \% \mathrm{Cl})$ & No. & $\%(95 \% \mathrm{Cl})$ & No. & $\%(95 \% \mathrm{Cl})$ \\
\hline \multicolumn{7}{|c|}{$\begin{array}{l}\text { With which healthcare professional would } \\
\text { you be likely to accept generic substitution? }\end{array}$} \\
\hline Hospital consultant/doctor $\left(n^{r}=179\right)$ & 124 & $69(62-76)$ & 46 & $26(19-33)$ & 9 & $5(2-9)$ \\
\hline General practitioner $\left(n^{r}=168\right)$ & 61 & $36(29-44)$ & 94 & $56(48-64)$ & 13 & $8(4-13)$ \\
\hline Pharmacist $\left(n^{r}=164\right)$ & 56 & $34(27-42)$ & 97 & $59(51-67)$ & 11 & $7(3-12)$ \\
\hline Nurse $\left(n^{r}=156\right)$ & 25 & $16(11-23)$ & 123 & $79(72-85)$ & 8 & $5(2-10)$ \\
\hline
\end{tabular}

$n^{r}=$ total number of patients responding to the question .

$\mathrm{Cl}=$ confidence interval. 
of branded and generic drugs that might affect clinical outcomes [31-34]. Some have also indicated that healthcare costs were higher for patients receiving generic versus branded medicine. One study revealed that total healthcare costs were significantly higher for patients receiving generic ciclosporin A compared to the branded form [15]. Another study reported that patients treated with the branded ciclosporin A had lower overall healthcare costs [16].

This study had a number of limitations. Attitudes toward generic substitution were mainly assessed from the patients' viewpoint and not that of healthcare professionals. The survey was completed in only 2 hospitals in the United Arab Emirates, the results cannot, therefore, be generalised to the whole country or region.

There were missing responses to many of the questions asked and this will have an effect on the results; therefore, these results have to be considered with caution.

\section{Conclusion}

Many patients were sceptical of accepting generic medicines and substitutions. Some considered cheaper drugs as being less effective and associated with increased adverse events. This can negatively affect patients' adherence to a medication regime. In addition, the regulations surrounding generic bioequivalence and substitution should be strengthened to maintain high quality of care. We believe that random generic substitution should notbeimplemented because there is uncertainty and lack of knowledge on the patients' side. Proper patient education and monitoring and involving patients in decision regarding their health may improve transparency around the practice of generic substitution, enhance patients' assurance and promote efficient prescribing.

\section{Acknowledgements}

The authors are grateful to all the pharmacists and renal dialysis staff in both the UAE General Hospital and the UAE University Hospital for recruiting patients to participate in this study. We are also thankful to all participating patients and to the government of the United Arab Emirates for supporting and encouraging independent research. Funding: This survey was funded by the William Harvey Research Institute at Queen Mary University of London. M. Al Ameri was supported by the Government of the United Arab Emirates, Abu Dhabi.

Competing interests: None declared.

\section{References}

1. Bloor K, Maynard A, Freemantle N. Lessons from international experience in controlling pharmaceutical expenditure. III: Regulating industry. BMJ (Clinical Research Ed.), 1996. 313(7048):33-35.

2. [The medicinal consumption in the UAE has reached four billion Dirhams in 2010.] Alittihad (online newspaper), March 5th, 2011 [in Arabic].

3. Andersson $\mathrm{K}$ et al.What are the obstacles to generic substitution? An assessment of the behaviour of prescribers, patients and pharmacies during the first year of generic substitution in Sweden. Pharmacoepidemiology and Drug Safety, 2005, 14(5):341-348.

4. Tilson L, Bennett K, Barry M. The potential impact of implementing a system of generic substitution on the community drug schemes in Ireland. European Journal of Health Economics, 2005, 6(3):267-273.

5. Abu Dhabi moves towards generic prescribing. Datamonitor, 20 April 2009 (http://www. datamonitor.com/store/News/abu_dhabi_moves_towards_ generic_prescribing?productid=0F02EAF3-3EAB-4C7C-87F68530E731DA65, accessed 14 Jan 2013).

6. Himmel $\mathrm{W}$ et al. What do primary care patients think about generic drugs? International Journal of Clinical Pharmacology and Therapeutics, 2005, 43(10):472-479.

7. Garattini S, Bertelé V. Non-inferiority trials are unethical because they disregard patients' interests. Lancet, 2007, 370(9602):1875-1877.

8. Duerden MG, Hughes DA. Generic and therapeutic substitutions in the UK: are they a good thing? British Journal of Clinical Pharmacology, 2010, 70(3):335-341.

9. Chow S-C. Individual bioequivalence-a review of the FDA Draft Guidance. Drug Information Journal, 1999, 33:435-444.
10. AlAmeri M, Epstein M, Johnston A. Generic and therapeutic substitutions: are they always ethical in their own terms? Pharmacy World \& Science, 2010, 32(6):691-695.

11. Christians U, Klawitter J, Clavijo CF. Bioequivalence testing of immunosuppressants: concepts and misconceptions. Kidney International, 2010, 77(115 Suppl.):S1-S7.

12. Generic substitution terminated for oral medicines containing cyclosporine or tacrolimus. Sundhedsstyrelsen, July 13th 2011, Danish Health and Medicines Authority (http://laegemiddelstyrelsen.dk/en/topics/authorisation-and-supervision/ licensing-of-medicines/news/generic-substitution-terminated-for-oral--tacrolimus, accessed 21 January 2013).

13. Prescriptions dispensed in the community: statistics for 1996 to 2006. London, NHS National Statistics, The NHS Information Centre (Health Care) (Bulletin: IC 2007 11. 11).

14. Dombrowski C. UK drug pricing scheme to allow generic substitution, promote innovation. EuroPharma Today, November 24, 2008 (http://www.europharmatoday.com/2008/11/ukdrug-pricing-scheme-to-allow-generic-substitution-promoteinnovation.html, accessed 21 january 2013).

15. Helderman JH et al. Healthcare costs in renal transplant recipients using branded versus generic ciclosporin. Applied Health Economics and Health Policy, 2010, 8(1):61-68.

16. Kingma I et al. Economic analysis of Neoral in de novo renal transplant patients in Canada. Clinical Transplantation, 1997, 11(1):42-48.

17. Cox DC et al. Guidelines for dissolution testing. Pharmaceutical Technology, 1978, 2(4):40-53.

18. Kamerow D. The pros and cons of generic drugs. BMJ, 2011, 343:d4584.

19. Bioequivalence and labelling of medicinal products with regard to generic substitution. Sundhedsstyrelsen, July 
13th 2011, Danish Health and Medicines Authority (http:// www.dkma.dk/en/topics/authorisation-and-supervision/ licensing-of-medicines/marketing-authorisation/applicationfor-marketing-authorisation/bioequivalence-and-labellingof-medicine--bstitution, accessed 21 january 2013).

20. Frank RG. The ongoing regulation of generic drugs. New England Journal of Medicine, 2007, 357(20):1993-1996.

21. Kozlowski $S$ et al. Developing the nation's biosimilars program. New England Journal of Medicine, 2011, 365(5):385-388.

22. Al Ameri MN et al. A survey to determine the views of renal transplant patients on generic substitution in the UK. Transplant International, 2011, 24(8):770-779.

23. Meredith P. Bioequivalence and other unresolved issues in generic drug substitution. Clinical Therapeutics, 2003, 25(11):2875-2890.

24. Weinman J. Providing written information for patients: psychological considerations. Journal of the Royal Society of Medicine, 1990, 83:303-305.

25. AbduelkaremAR, SharifSI. Current levels of interaction between the physician and pharmacist: a comparative study in Libya and UAE. Jordan Journal of Pharmaceutical Sciences, 2008, 1(2):142-151.

26. UAE Guidelines of Bioequivalence Testing for Generic Pharmaceutical Products 2001. Dubai, United Arab Emirates, Ministry of Health, 2011 (http://www.cpd-pharma.ae/index. php?option=com_phocadownload\&view=category\&id=2\&lte mid=78\&limitstart=20, accessed 21 January 2013).
27. Simoens S. Generic and therapeutic substitution: ethics meets health economics. International Journal of Clinical Pharmacology, Therapy and Toxicology, 2011, 33(3):469-470.

28. Masri M. The generics in transplantation and the rules on their use. Experimental and Clinical Transplantation, 2003, 1(1):65-68.

29. Berg MJ et al. Generic substitution in the treatment of epilepsy: case evidence of breakthrough seizures. Neurology, 2008, 71(7):525-530.

30. Richton-Hewett S, Foster E, Apstein CS. Medical and economic consequences of a blinded oral anticoagulant brand change at a municipal hospital. Archives of Internal Medicine, 1988, 148(4):806-808.

31. Kovarik JM et al. Differentiation of innovator versus generic cyclosporine via a drug interaction on sirolimus. European Journal of Clinical Pharmacology, 2006, 62(5):361-366.

32. Qazi YA et al. The clinical impact of 1:1 conversion from Neoral to a generic cyclosporine (Gengraf) in renal transplant recipients with stable graft function. Clinical Transplantation, 2006, 20(3):313-317.

33. Taber DJ et al. Does bioequivalence between modified cyclosporine formulations translate into equal outcomes? Transplantation, 2005, 80(11):1633-1635.

34. Approved drug products with therapeutic equivalence evaluations (Orange book). Silver Springs, Maryland, US Food and Drug Administration, 2009. 